\title{
The contribution of reading interest on literature and reading comprehension toward students' ability in writing fantasy story
}

\author{
Sri Endah ${ }^{1}$, Harris Effendi Thahar ${ }^{2}$, Yasnur Asri ${ }^{3}$ \\ ${ }^{123}$ Universitas Negeri Padang, Padang - Indonesia, (sriendah1992@gmail.com)
}

\begin{abstract}
The purpose of this research was to figure out the contribution of reading interest on literature and reading comprehension toward students' ability in writing fantasy story of VII grade of junior high schools in Padang. This research was quantitative research that applied correlational method. The sample were 106 students. The sampling technique was stratified random sampling. Data were analyzed by using Pearson Product Moment Correlational test, multiple regression, $\mathrm{t}$ test, and $\mathrm{F}$ test. The result shown that first, the reading interest on literature contributed $61,3 \%$. Second, the reading comprehension on fantasy story contributed $55,5 \%$. Third, both of the reading interest on literature and reading comprehension on fantasy story contributed $63,8 \%$. Thus, reading interest on literature and reading comprehension on fantasy story gave contribution and significant relationship toward ability in writing fantasy story text.
\end{abstract}

Keywords: fantasy story, interest of literature

\section{Introduction}

Writing is a productive activity. This activity requires ongoing training. This writing exercise expects students to be able to express ideas, opinions, and knowledge in writing. Writing activities require various strategies and methods of learning. Astuti (2016) mentioned that teachers had teaching strategy to motivate students and this strategy gave a big influence on student learning outcomes at school. In addition, Salwa (2014) in her research findings explained that the implementation of teaching strategies was helpful for weak students to be able to interact with skilfull students. Mustafa (2017) mentioned that problem solving strategies help students to understand the reading. Dwiyogo (2018) explained that mixed learning methods have a positive impact on problem solving experienced by students. Furthermore, Kheryadi (2017) found the fact that playing techniques couldhelp students to write narrative text and students interested in learning while playing proved with better students' learning outcomes from each given cycle. Thus, learning activities require a lot of effort to improve students'learning outcomes.

Related with these activities, the form of writing skills are varies, one of them is writing fantasy story text. The result of Berold's (2015) study explained that reading and writing were important in teaching students to form the students' mindset. Furthermore, Rhodes and Brown (2005) mentioned that a writer who is responsible for writing his research will be able to distinguish writings that are 
fiction and nonfiction. Furthermore, David G, Robyn J, \& Spencer J (2014) say that a short story writer must have a broad ability to produce writing that can serve as a point in social science and so on.

The facts in the field show $\mathrm{n}$ that students' learning in Indonesia has not been encouraging. In fact, the lessons of students in Indonesia are more than developed countries. Theis imagination was also poor due to the method of rote. Indonesia has 1,095 hours of lessons per year, this is different from Japan which only impose 712 hours of lessons per year. In addition, Indonesia's ranking in the mastery of 15-year-old youth of science, reading, and mathematics (PISA) culture is still in the lower layer, (Kompas.com, 2016).

This literacy problem was reinforced by research findings by Esti S. and Setyawan, P. (2017) which reveal that literacy culture was manifested in reading and writing activities. However, there were still constraints coming from and within the surrounding environment. Research in line with literary issues was also stated by Hayati (2016) which states that the use of foreign languages in children's literature seems to make Indonesian language unable to represent the whole of childrens' expression. In addition, there are also problems related to reading activities of students. Suryaman (2015) found that the average achievement of Indonesian students' reading ability was at a low level below the international median. Suryaman's research was reinforced by Kirby (2011) through his findings related to reading interest explains that reading interest in grade 1 primary school was still low, but the higher the school level of students, there was correlation between reading interest with reading ability.

Furthermore, Gary P.M. and Timothy G. (1998) explained that teachers were advised to provide a basis for finding learning activities. It's to make students become interested in reading and help them to have a high reading interest. Research on reading interest was also conducted by Khairuddin. Khairuddin (2013) through the findings of his research revealed interest in reading was very important in changing the success of students both within and outside himself. Furthermore, Flynn (2016) conducted research on students'interest in reading comprehension. Based on the research, students and parents inquired about the types of books that interest them. In addition, teachers collected information about the types of books that students often borrow in the library and the type of text they read. Students were interested to compare their comprehension skills by reading fiction and nonfiction textbooks.

Literary interest reading, understanding fantasy texts and fantasy story writing were also found in schools based on interviews with teachers and students. The problems were as follows. First, students still had difficulty in writing sentences. Second, students found difficulties tobuild creativity that link to imagination. Third, the teacher was still in the early stages of introducing fantasy story writing material. Third, students consider writing lessons to be difficult less than other aspects such as listening, speaking, and reading. Fourth, students consider writing activities as boring. Fifth, students did not yet have an adequate reference source for writing fantasy story texts. Sixth, students have been given writing practice, but there was not enough space to do exercise.

Theoretically, Mahsun (2014:18-19) explains that the fantasy story text is a genre of narrative literature that has a social purpose of telling events. The text of the fantasy story has a social purpose of telling the solution of a problem with a pleasant finish. The structure of fantasy story text is: recognition (orientation), problem (complication), and problem solving (resolution). The structural problems of the story were also explained by Thahar (2009:17-36) that there were several points to consider in writing a story. First, the first paragraph. Second, consider the reader. Third, dig up the atmosphere. Fourth, the sentence must be effective effective. Fifth, spices. Sixth, move the character (character). Seventh, the focus of the story. Eighth, final jolt. Ninth, edit. Tenth, give the title.

Furthermore, issues related to interest were explained by Sutikno (2009:16). Interest is a sense of interest in something or activity without anyone telling and forcing it. According to Iskandarwassid and Suhendar (2009:113), interest is one of the important factors affecting reading ability. While 
Semiawan (in Iskandarwassid and Suhendar, 2009:113), states that interest is a mental state that produces a directional response to a particular situation or object that pleases and gives satisfaction to it. Furthermore, Dalman (2013:142) concludes that reading interest is an activity that is done with great diligence in order to establish a pattern of communication with oneself to find the meaning of writing and find information to develop intellectuals done with full awareness and feelings of pleasure that arise from within him . Furthermore, Razak (2005:79) states that interest in reading was a linguistic condition that contains two aspects. Rahim (2009:28) explains that interest in reading was a strong desire accompanied by attempts to read something. The fantasy story is part of a fictional story. This opinion was delivered by Nurgiyantoro (2005:297) that fantasy is a story whose degree of truth is in doubt. What was told in the story is illogical, at least in certain passages. Meanwhile, Alek and Achmad (2010:81) state that reading comprehension was a reading strategy that aims to provide an assessment of the papers that engage themselves on a reading and make an appropriate analysis of the passage.

Therefore, this research was conducted to find out (1) the contribution of literature reading to the skill of writing fantasy story text of the seventh grade students of Junior High Schools in Padang. (2) The contribution of skills to understand the text of fantasy tales on the skill of writing the fantasy story text of the seventh grade students of Junior High Schools in Padang. (3) The contribution of literary interest and the skill of understanding fantasy texts together to the writing skill of fantasy story of the seventh grade students of Junior High Schools in Padang.

\section{Method}

The sample in this study were the seventh grade students of Junior High Schools in Padang. There were 106 students involved. The sampling technique was done proportionate stratified random sampling. This type of research was quantitative research using descriptive method and correlational design. Data analysis technique was done through several stages. First, gving a score on each questionnaire and test given. Second, turning the raw score into value. Third, creating a frequency distribution table and bar chart for each variable. Fourth, determining the average score. Fifth, testing the significance. Sixth, testing the hypothesis. Seventh, testing the amount of contribution. Eighth, performing simple regression testing.

\section{Results and Discussion}

The data in this research consisted of three variables, namely reading interest on literature variable $(\mathrm{X} 1)$, skill variables $(\mathrm{X} 2)$, and the skill of writing fantasy story text $(\mathrm{Y})$. Data descriptions of three variables in this research could be seen as follows.

1. Data of Writing Skills of Fantasy StoriesText

The average value of fantasy story writing skills was 80.85 . The results obtained there were 21 students or $19.81 \%$ of the number of students whobelonged to the average group. Students who scored below the average interval class were 45 students or $42.44 \%$, while the students who scored above the average interval class were 40 students or $37.75 \%$.

2. Data of Reading Interest on Literature

The average reading interest on literature was 80.85 . The results obtained were 31 students or $29.25 \%$ of the students were in above averagegroup. Students who scored below the average interval class were 48 students or $45.28 \%$, while students who scored above the average interval class were 37 students or $34.90 \%$.

3. Skills Data Understanding Text Fantasy Story

The average value of the skill of understanding fantasy texts was 79.69. Results obtained there were 13 students or $12.26 \%$ of the number of students who belonged to average group, that was 
79.69. Students who scored below the average interval class amounted to 47 students or $44.34 \%$, while students who scored above the average interval class were 46 students or $43.4 \%$.

Furthermore, the result of the calculation has been done that the data of the three research variables were gotten from the normal distributed population. This was evident from $\mathrm{L} 0<\mathrm{Lt}$ at the alpha significance level $=0.05$ with $\mathrm{dk}=106$. $\mathrm{Lt}$ at the alpha significance level $=0.05$ was 0.086 . Based on the calculation results could also be concluded that the research datawere gotten from a homogeneous sample. This was because X2 count was smaller than X2 table or 3,1430<5,991 at a significant level of 0.05 with $\mathrm{dk}=2$. The results of linearity test data also shows that there was a linear relationship and significant interest in literature reading (X1) with the skills of writing fantasy story (Y). Both variables were expressed linear because Fcount $<$ Ftable was $1.14<1.65$. In addition, both variables are significant because Fcount $>$ Ftable was $167.17>3.07$. Thus, there was a significant relationship between literacy interest (X1) to the skills of writing fantasy story (Y).

Furthermore, there was a linear and significant relationship between the skill of understanding fantasy story text $(\mathrm{X} 2)$ with the skill of writing fantasy story $(\mathrm{Y})$. Both variables were expressed linear because Fcount $<$ Ftable, that was $0.98<1.83$. In addition, both variables were significant because Fcount $>$ Ftable is $127.43>3.07$. Having known the relationship of each research variable, the meal was done hypothesis testing. First, the interest of literature reading (X1) contributes to the variable of fantasy story writing skills were $(\mathrm{Y})$ obtained by tcount $>$ ttable or $12,81>1,66$. Thus, H0 was rejected and $\mathrm{H} 1$ was accepted. Second, the skill of understanding fantasy story text (X2) contributed to the variable of fantasy story writing skill (Y) was obtained tcount $>$ ttable or 11,38 $>1,66$. Thus, H0 was rejected and H1 was accepted. Thirdly, the interest of literary reading (X1) and the skill of understanding fantasy story text $(\mathrm{X} 2)$ together contributes to the variable of fantasy story writing skills (Y) obtained Fcount > Ftable or 106,33 > 1,66. Thus, H0 was rejected and H1 was accepted.

Based on the test of double correlation significance, it could be concluded that the form of relationship between literacy interest and the skill of understanding fantasy texts in line with the variable of fantasy story writing skill was significant because Fcount $>$ Ftable or 31,42 > 1,66. Therefore, if you want to improve the results of writing skills, then the interest of literary reading and skills to understand the text of fantasy stories of students should be improved.

Based on the analysis of the three research hypotheses, the following results were obtained. First, the relationship and literary interest contributed to the writing of fantasy story text ( $\mathrm{rX1Y}=0.783$ and $\mathrm{KP}=61.3 \%$ ). Second, relationship and skill contributed to understanding of fantasy story texts on fantasy story writing skills ( $\mathrm{rX} 2 \mathrm{Y}=0.745$ and $\mathrm{KP}=55.5 \%)$. Third, the relationship and the contribution of literary interest and the skills of understanding fantasy texts in line with the writing skills of fantasy story text $(\mathrm{rX} 1 \mathrm{X} 2 \mathrm{Y}=0.615$ and $\mathrm{KP}=37.82 \%)$.

The contribution of literary interest to the writing of fantasy texts based on the research results could be concluded that literary interest contributed significantly to the skill of writing fantasy story text. The interest of literature reading was one of the factors that contributed to the skill of writing fantasy stories. The higher students' reading interest on literature, the higher students' skill of writing the fantasy story. Thus, students who had low scorein writing fantasy stories text could be improved by increasing students' interest in reading literary. Teachers and parents also needed to work on improving students 'reading interest so that their students' writing skills would be better. Teachers were supposed to guide students to have a good reading interest and good ability in writing fantacy story.

Based on the results of the study also could be concluded that the skills to understand the text of fantasy stories made a significant contribution to the writing skills of fantasy story text. The skill in understanding fantasy texts was one of the factors that contributed to the skill of writing fantasy texts. The higher the students' understanding of the fantasy texts, the higher the skill of writing 
fantasy stories. Thus, the low value of the writing skills of fantasy tales could be improved by increasing students' understanding of fantasy texts. Teachers are supposed to guide students to have a good and good understanding of fantasy story text and invite students to be skilled in writing, especially writing fantasy story texts.

Furthermore, the results of the study also shown that both ofreadinginterest on literary and the skill of understanding fantasy texts made a significant contribution to the writing skills of fantasy story text. Thus, students who had low skill of writing fantasy story texts could be enhanced by increasing their interest of literary reading and the skill of understanding the text of fantasy stories. Based on the research findings, it could be concluded that the skill of writing the fantasy story of the seventh grade students of junior high schools in Padang must be improved even though the achievement level of students' writing skill test have been good.

\section{Conclusions}

Based on the results of research and discussion, it could be concluded that First, the contribution of literary interest to the writing of fantasy texts was $61.3 \%$. Secondly, the contribution of the skill of understanding fantasy texts toward the writing of fantasy texts was $55.5 \%$. Third, the contribution of readinginterest on literature and the skill of understanding fantasy textsin line the skill of fantasy story writing was $63,8 \%$. This shows that the interest of readingliterature and the skill of understanding fantasy texts were some of the factors that contributed to the writing skills of fantasy story writing. Students who had an interest inreading literature and the skill of understanding good fantasy texts could certainly improve their fantasy story writing skills. Therefore, efforts to increase the interest of literary reading and the skill of understanding fantasy texts wer needed to be maximized.

\section{Acknowledgments}

This article was written as one of the requirements to meet some requirements to obtain Master of Education degree in Indonesian Language and Literature Education Program, State University of Padang. Therefore, thanks go to the mentors and contributors of the thesis who have helped to provide criticism, suggestions, or feedback. Furthermore, thanks go to reviewers who have read, corrected, and provided input to this research article.

\section{References}

Alek \& Achmad. (2010). Bahasa Indonesia untuk perguruan tinggi. Jakarta: Kencana.

Astuti, D.P. (2013). Minat baca penentu kualitas bangsa. Jurnal Ilmiah Teknologi Pendidikan UNNES, (5),

2.

Berold, R. (2015). What do writing students need? The rhodes masters in creative writing. TANDFONLINE Journal. (27), 2, 139-144.

Dalman, H. (2013). Keterampilan membaca. Jakarta: RajaGrafindo Persada.

David G, Robyn J, \& Spencer J (2014). Applied utility and the auto- ethnographic short

story: persuasions for, and illustrations of, writing critical social science. Journal Sport, Ediucation and Society, (19), 1.

Dwiyogo,Wasis D. (2018). Developing a blended learning-based method for problem-solving in capability learning. Journal TOJET: The Turkish Online Journal of Educational Technology, 17 (1), 5161.

Esti S. dan Setyawan, P. (2017). Budaya literasi di kalangan mahasiswa FBS UNY. Jurnal LITERA, (16), $1,105-113$. 
Flynn, K.O. (2016). Students' reading interests impact on reading comprehension abilities. School of arts and sciences St. John Fisher College, Rochester, New York.

Gary P.M. dan Timothy G.M (1998). Increasing students' achievement and interest in reading. The Berkeley Electronic Press (bepress), (38).

Hayati, Y. (2016). Pemakaian bahasa asing dalam sastra anak karya anak di Indonesia. Humanus: Jurnal Ilmiah Ilmu-ilmu Humaniora, (XV), 2, 226-235.

Iskandarwassid dan Suhendar, D. (2009). Strategi pembelajaran bahasa. Bandung: Remaja Rosdakarya.

Khairuddin, Z. (2013). A study of students' reading interests in a second language. international education studies. Published by Canadian Center of Science and Education, 6 (11), ISSN 1913-9020.

Kheryadi. (2017). Improving students' writing narrative through writing games for acceleration class. EDULITE Journal, (2) 2, 377-388.

Kirby, John R. (2011). The development of reading interest and its relation to reading ability. Journal of Research in Reading, (32), 3, 263-280.

Kompas. (2016). Daya imajinasi siswa lemah. Artikel.

Mahsun. (2014). Teks dalam pembelajaran bahasa Indonesia kurikulum 2013. Jakarta: RajaGrafindo Persada.

Mustafa, U (2017). The effect of reading comprehension and problem solving strategies

on classifying elementary 4 th grade students with high and low problem solving success. Journal of Education and Training Studies, (5), 6.

Nurgiyantoro, B. (2005). Sastra anak: pengantar pemahaman dunia anak. Yogyakarta: Gajah Mada University Press.

Rahim, F. (2009). Pengajaran membaca di sekolah dasar. Jakarta: Bumi Aksara.

Razak, A. (2005). Membaca pemahaman teori dan aplikasi pengajaran. Pekanbaru: Autografika.

Rhodes, C \& Andrew D. B. (2005). Writing responsibly: narrative fiction and organization studies. SAGE JUORNALS, First Published July 1.

Salwa. (2014). Considerable strategies of teaching large multi-level classes: a narrative study of what EFL teachers should do. IJEE journal, (1) 1, 95-106.

Suryaman, M. (2015). Analisis hasil belajar peserta didik dalam literasi membaca melalui studi internasional (PIRLS) 2011. Jurnal LITERA, (14), 1, 171-186.

Sutikno, S. (2009). Belajar dan pembelajaran. Bandung: Prospect.

Thahar, H.E. (2009). Kiat menulis cerita pendek. Bandung: Angkasa Bandung. 